\title{
Evaluasi Organoleptik Multinutrien Blok yang Dibuat dengan Menggunakan Metode Dingin pada Perbedaan Aras Molases
}

Organoleptic Evaluation of Multinutrient Block Processed by the Cold Methods on Different Level of Mollases

| S Handayani¹, B | M Tampoebolon¹, A Subrata', R | Pujaningsih¹, Widiyanto'

Corresponding email: istikasrihandayani321@gmail.com

1) Fakultas Peternakan Universitas Dipenogoro

\section{ABSTRACT}

This research aimed to evaluated and assessed the effect of the molasses level on organoleptic quality of multinutrient block (MnB). The materials used were corn forage, bentonite, urea, salt, molasses, water, blood clamshell and egg shells. The experimental designed used was a Completely Randomized Design with 4 treatments (T0 $=\mathrm{MnB}$ Formulation $\mathrm{T} 0+0 \%$ of molasses, $\mathrm{T} 1=\mathrm{MnB}$ Formulation $\mathrm{T} 1+20 \%$ of molasses, $\mathrm{T} 2=\mathrm{MnB}$ Formulation $\mathrm{T} 2+35 \%$ of molases, and T3 $=$ MnB Formulation T3 $+50 \%$ of molasses) and 4 replications. The variables observed were moisture content, texture, colored and aroma of $\mathrm{MnB}$. The results showed that the addition of molasses had significantly $(\mathrm{P}<0.05)$ improved of MnB organoleptic quality. The conclusion for the study, that the multinutrient block formulation with $50 \%$ molasses resulted the best organoleptic quality.

Key words: molasses, multinutrient block, organoleptic quality

\section{ABSTRAK}

Penelitian ini bertujuan untuk mengevaluasi dan mengkaji pengaruh aras molases terhadap kualitas organoleptik multinutrien blok $(\mathrm{MnB})$. Bahan yang digunakan dalam penelitian adalah hijauan jagung, bentonit, urea, garam, molases, air, cangkang kerang darah dan cangkang telur. Penelitian dilaksanakan menggunakan rancangan acak lengkap dengan 4 perlakuan aras molases $(\mathrm{T} 0=$ Formulasi $\mathrm{MnB}$ T0 $+0 \%$ molases, $\mathrm{T} 1=$ Formulasi MnB T1 + $20 \%$ molases, T2 = Formulasi MnB T2 + 35\% molases, dan T3 = Formulasi MnB T3 + 50\% molasses) dan 4 ulangan. Variabel yang diamati adalah kadar air, tekstur, warna dan aroma MnB. Hasil penelitian menunjukkan bahwa penambahan molases memiliki pengaruh yang signifikan $(\mathrm{P}<0,05)$ terhadap peningkatan kualitas organoleptik MnB. Berdasarkan hasil penelitian dapat disimpulkan formulasi multinutrien blok dengan pemberian aras molases sebanyak $50 \%$ memiliki kualitas organoleptik paling baik.

Kata kunci: aras molasses, kualitas organoleptik, multinutrien blok 


\section{PENDAHULUAN}

Pakan merupakan komponen yang mempunyai persentasi terbesar dari seluruh total biaya produksi. Pakan sangat penting untuk diperhitungkan karena digunakan untuk kelangsungan hidup, produksi dan juga reproduksi bagi ternak. Kendala yang sering dijumpai pada penyediaan pakan di Indonesia adalah kualitas pakan yang rendah terutama pada kandungan nutrien didalamnya. Kekurangan nutrien dapat mengganggu proses metabolisme tubuh dan menurunkan efisiensi serta produktivitas dari ternak. Penurunan produktivitas ternak dapat tercermin dari penurunan pertambahan bobot badan.

Permasalahan kekurangan nutrien pada ternak dapat diatasi dengan melakukan suplementasi nutrien. Suplementasi multinutrien yang tepat yaitu mengandung energi, protein dan mineral. Multinutrien blok merupakan pakan pelengkap yang diberikan untuk ternak ruminansia berbentuk balok maupun silinder padat yang mengandung energi, protein dan mineral di dalamnya (Garcia \& Restrepo 1995). Pakan pelengkap yang diberikan diharapkan dapat memenuhi kebutuhan nutrien bagi ternak sehingga dapat meningkatkan produktivitasnya. Multinutrien blok dapat terbuat dari bahan-bahan seperti hijauan jagung, bentonit, urea, garam, sumber mineral seperti cangkang kerang dan cangkang telur serta molases.

Mineral pada tubuh ternak dibagi menjadi dua kelompok yaitu mineral esensial dan non esensial. Defisiensi mineral pada ternak dapat menimbulkan penyakit, menghambat pertumbuhan dan perkembangan bahkan dapat mengakibatkan kematian. Kelompok mineral esensial dalam tubuh dibagi menjadi mineral makro dan mineral mikro. Pembuatan multinutrien blok dengan menggunakan cangkang kerang darah (Anadara granosa) dan cangkang telur sebagai sumber mineral terutama kalsium dan Phospor merupakan salah satu upaya dalam pemanfaatan hasil samping. Cangkang kerang darah dan cangkang telur mempunyai keunggulan dalam kandungan mineral yang tinggi terutama Ca dan P yang dibutuhkan dalam tubuh dalam jumlah yang cukup besar dan ketersediaan bahan juga sangat melimpah. Kandungan mineral pada cangkang kerang darah yaitu 98\% CaCO3, 0,20\% $\mathrm{Mg}$, 0,87\% $\mathrm{Na}, 0,02 \% \mathrm{P}$ dan 0,04\% K (Zakaria et al., 2004). Kandungan mineral pada cangkang telur yaitu 90,9\% CaCO3, 0,12\% P, 0,15-0,17\% Na, 0,37-0,40\% Mg, 0,100,13\% K dan 0,09-0,19\% S (Warsy et al. 2016).

Penilaian kualitas multinutrien blok dapat dilakukan dengan pengujian secara organoleptik dan uji kandungan kadar air. Pengujian kadar air dilakukan untuk mengetahui kandungan air yang berada dalam suatu pakan untuk menentukan lama penyimpanan. Pengujian organoleptik dilakukan dengan pengujian tekstur, warna dan aroma pakan. Kualitas multinutrien blok dari segi organoleptik juga ditentukan oleh jenis serta jumlah penggunaan binder yang tepat. Molases digunakan untuk perekat (binder) dari bahan penyusun multinutrien blok utamanya bahan sumber serat. Syarat penggunaan binder diantaranya yaitu mudah diperoleh, harganya murah, tidak bersaing dengan kebutuhan manusia dan tidak mengganggu kandungan nutrien yang terdapat dalam ransum. Tujuan penelitian untuk mengevaluasi dan mengkaji pengaruh aras molases terhadap kualitas organoleptik multinutrien blok. Hipotesis penelitian ini adalah penambahan molases akan mempengaruhi kualitas multinutrien blok (MnB).

\section{METODE}

\section{Materi}

Materi yang digunakan dalam penelitian adalah hijauan jagung, molases, garam, cangkang kerang darah, cangkang telur, urea dan bentonit serta panelis semi terlatih sebanyak 20 orang untuk menguji kualitas organoleptik pembuatan MnB. Alat yang digunakan meliputi disc mill dengan ukuran saringan $0,03 \mathrm{~mm}$, timbangan digital kapasitas $5 \mathrm{~kg}$ ketelitian 0,05g, cetakan dari paralon, ember, plastik, dan kuisioner untuk menguji kualitas organoleptik.

\section{Prosedur}

Kegiatan penelitian ini dilakukan melalui tiga tahap yaitu tahap persiapan, tahap pembuatan multinutrisi blok dan tahap pengambilan data.

\section{Tahap persiapan}

Tahap persiapan meliputi survei pembelian bahan baku, pengadaan bahan pakan dan tahap pembuatan formulasi. Formulasi multinutrien blok dapat dilihat Tabel 1.

\section{Tahap persiapan $\mathrm{MnB}$}

Tahap pembuatan MnB pakan kambing yaitu bahan pakan yang digunakan dikumpulkan berupa hijauan jagung, garam, cangkang kerang darah, cangkang telur, urea, molasses dan bentonit. Hijauan jagung, cangkang kerang darah dan cangkang telur yang sudah kering digiling menggunakan disc mill dengan ukuran saringan 0,03 mm. Bahan pakan ditimbang sesuai dengan formulasi yang telah dibuat. Tahap selanjutnya yaitu semua bahan yang telah ditimbang dicampur. Tahap terakhir adalah MnB dicetak kemudian dikeringkan dibawah naungan tanpa terkena sinar matahari secara langsung dan tahap terakhir dilakukan pengujian kualitas organoleptik MnB. Multinutrien blok dibuat dengan empat macam perlakuan: 
Tabel 1 Komposisi bahan multinutrien blok (MnB)

\begin{tabular}{lllll}
\hline \multirow{2}{*}{ Bahan } & \multicolumn{4}{c}{ Perlakuan } \\
\cline { 2 - 5 } & T0 & T1 & T2 & T3 \\
\hline \multirow{2}{*}{ Molases } & $-------------(\%)----------$ \\
Hijauan Jagung & 0 & 20 & 35 & 50 \\
Garam & 50 & 40 & 35 & 30 \\
Cangkang kerang darah & 5 & 5 & 5 & 3 \\
Cangkang telur & 15 & 10 & 6 & 3 \\
Urea & 15 & 10 & 6 & 3 \\
Bentonit & 5 & 5 & 4 & 4 \\
\hline Total & 10 & 10 & 9 & 7 \\
\hline T0 : Formulasi MnB T0 (Molases 0\%) \\
T1 : Formulasi MnB T1 (Molases 20\%) \\
T2 : Formulasi MnB T2 (Molases 35\%) \\
T3 : Formulasi MnB T3 (Molases 50\%
\end{tabular}

\section{Tahap penilaian parameter}

Penilaian variabel penelitian meliputi uji fisik kadar air menurut metode Pratama et al. (2016). Variabel lain yaitu kualitas organoleptik meliputi warna, tekstur dan aroma yang di uji menurut metode Fathia (2006).

1. Kadar Air

Pengujian tahap ini dilakukan dengan pengovenan pada suhu $110^{\circ} \mathrm{C}$ sampai berat konstan.

2. Tekstur, Warna dan Aroma

Pengukuran tekstur, warna dan aroma dilakukan dengan bantuan 20 orang panelis semi terlatih untuk membandingkan kualitas organoleptik $\mathrm{MnB}$ antar perlakuan.

\section{Analisis Data}

Rancangan percobaan yang digunakan adalah rancangan acak lengkap dengan 4 perlakuan dan 4 ulangan sehingga terdapat 16 unit percobaan dan apabila terdapat perbedaan yang signifikan dilanjutkan dengan uji Duncan Multiple Range Test untuk mengetahui perbedaan antar perlakuan.

\section{HASIL DAN PEMBAHASAN}

Uji kualitas organoleptik multinutrien blok dilakukan dengan 20 panelis semi terlatih. Hasil uji organoleptik dapat diketahui hasil pada Tabel 2.

\section{Kadar Air}

Perbedaan aras molases berpengaruh nyata $(p<0,05)$ meningkatkan nilai kadar air multinutrien blok. Kadar air antar perlakuan T1, T2 dan T3 memiliki nilai kadar air lebih tinggi dibandingkan dengan $\mathrm{T} 0(\mathrm{p}<0,05)$.

Hasil analisis kadar air perlakuan T3 mempunyai nilai rata-rata paling tinggi dibandingkan perlakuan yang lain. Nilai kadar air yang tinggi pada perlakuan menunjukkan kualitas MnB yang kurang baik. Perlakuan yang paling baik terdapat pada penambahan level molases sebanyak $0 \%$ yaitu $28,45 \%$. Nilai kadar air dari suatu bahan pakan
Tabel 2 Rataan hasil perbedaan level molases terhadap kualitas fisik dan organoleptik MnB

\begin{tabular}{lcccc}
\hline \multirow{2}{*}{ Perlakuan } & \multicolumn{4}{c}{ Variabel } \\
\cline { 2 - 5 } & Kadar Air & Tekstur & Warna & Aroma \\
\hline T0 & $28,95^{\mathrm{d}}$ & $2,04^{\mathrm{d}}$ & $3,40^{\mathrm{d}}$ & $1,52^{\mathrm{d}}$ \\
T1 & $30,53^{\mathrm{c}}$ & $2,29^{\mathrm{c}}$ & $3,11^{\mathrm{c}}$ & $1,93^{\mathrm{c}}$ \\
T2 & $31,58^{\mathrm{b}}$ & $2,41^{\mathrm{b}}$ & $2,83^{\mathrm{b}}$ & $2,47^{\mathrm{b}}$ \\
T3 & $41,82^{\mathrm{a}}$ & $2,75^{\mathrm{a}}$ & $2,89 \mathrm{a}$ & $3,04^{\mathrm{a}}$ \\
\hline
\end{tabular}

Keterangan: Superskrip yang berbeda pada kolom yang sama menunjukkan perbedaan yang nyata $(\mathrm{P}<0,05)$

dapat dipengaruhi oleh komposisi dan sifat dari bahan penyusun pakan. Semakin tinggi nilai kadar air dari bahan maka semakin tinggi kadar air dari bahan pakan yang dihasilkan. Penambahan aras molases sebagai perekat dapat mempengaruhi nilai kadar air suatu bahan. Syahri et al. (2018) menyatakan bahwa perekat dalam penyusunan bahan pakan merupakan faktor yang berperan penting peningkatan kadar air. Molases mempunyai sifat higroskopis sehingga kadar air dalam perlakuan mempunyai kandungan air yang tinggi. Nilai kadar air yang terdapat dalam multinutrien blok dari semua perlakuan menunjukkan hasil yang lebih tinggi dari standar penyimpanan bahan pakan, yaitu lebih dari 14. Tingginya nilai kadar air dalam semua perlakuan dapat mengakibatkan $\mathrm{MnB}$ mudah tercemar pada saat penyimpanan. Triyanto (2013) menyatakan bahwa nilai kadar air untuk menekan aktivitas mikroba yaitu 12-14 $\%$. Kadar air yang terlalu tinggi dapat menyebabkan pertumbuhan mikroba berjalan dengan cepat.

\section{Tekstur}

Nilai rata-rata tekstur multinutrien blok pada perlakuan masing-masing T0, T1, T2 dan T3 karakteristik semakin tinggi nilai rata-rata skor maka akan semakin halus tekstur bahan (Tabel 2). Penambahan aras molases pada pembuatan $\mathrm{MnB}$ berpengaruh nyata $(\mathrm{p}<0,05)$ meningkatkan tekstur MnB menjadi semakin halus. Ratarata nilai tekstur $\mathrm{MnB}$ tertinggi terdapat pada perlakuan penambahan aras molases sebanyak 50\% (T4) yaitu 2,75, sedangkan rata-rata terendah terdapat pada perlakuan penambahan molases sebanyak $0 \%$ (T1) yaitu 2,04 .

Faktor yang mempengaruhi tekstur MnB yaitu tingkat kehalusan bahan, jenis perekat, jumlah perekat yang digunakan dan jumlah serat yang digunakan. Ismi et al. (2017) menyatakan bahwa tingkat kehalusan bahan, jumlah serat dan jenis perekat merupakan faktor yang mempengaruhi tekstur pakan. Tekstur pakan yang semakin halus akan meningkatkan kapasitas konsumsi yang akan berpengaruh terhadap laju dan kecernaan pakan sehingga akan meningkatkan metabolism penyerapan. Hal ini sesuai dengan pendapat Toharmat et al. (2005) bahwa ketahanan partikel dan ukuran partikel pakan dapat mempengaruhi kondisi penyerapan nutrisi rumen. Kurnia et al. (2012) menyatakan bahwa ukuran 
partikel yang semakin kecil dapat memperluas area permukaan partikel sehingga menyebabkan interaksi kimia yang lebih optimal dalam penyerapan nutrisi ke dalam sel.

\section{Warna}

Hasil rata-rata nilai warna MnB pada T0, T1, T2 dan T3 terlihat pada Tabel 2. Pemberian aras molasses berpengaruh nyata $(\mathrm{p}<0,05)$ menurunkan kualitas warna MnB. Nilai T0 nyata lebih tinggi $(\mathrm{P}<0,05)$ dibandingkan dengan semua perlakuan yang lain yakni 3,40. Perlakuan T0 mempunyai nilai lebih tinggi dikarenakan mempunyai karakteristik warna yang lebih cerah dibandingkan perlakuan yang lain.

Penambahan aras molases hingga 50\% menyebabkan perubahan warna pakan menjadi lebih gelap. Warna gelap yang ada disebabkan oleh warna dasar molases yang cenderung coklat kehitaman. Widiastuti (2013) menyatakan bahwa semakin tinggi molases yang terserap ke dalam bahan pakan maka akan berpengaruh terhadap warna pakan menjadi lebih pekat. Hermawan et al. (2015) menyatakan bahwa warna coklat pada pakan merupakan hasil dari reaksi karbohidrat (reaksi Maillard), yang mana gula pereduksi dengan amino primer menghasilkan senyawa melanoid. Warna pakan tidak mempengaruhi palatabilitas ternak terhadap pakan yang akan dimakan. Faktor yang mempengaruhi tingkat konsumsi ternak yaitu aroma dan rasa. Syukur dan Suharno (2014) menyatakan bahwa sifat fisik dan organoleptik yang dapat menumbuhkan daya tarik dan rangsangan untuk mengkonsumsinya yaitu dapat dilihat dari penampilan, bau, rasa, tekstur dan suhu dari bahan pakan. Karakteristik warna pada pakan tidak mempengaruhi penerimaan ternak dalam mengkonsumsi pakan namun berpengaruh terhadap daya tarik terhadap konsumen dalam pemilihan.

\section{Aroma}

Hasil skor rata-rata uji organoleptik aroma terdapat pada Tabel 2. Penambahan aras molases pada pembuatan MnB berpengaruh nyata $(\mathrm{P}<0,05)$ terhadap aroma multinutrien blok. Nilai tertinggi diperoleh pada perlakuan T3 yakni 3,05 karena mempunyai aroma yang lebih harum dibandingkan perlakuan yang lain. Aroma yang paling disukai terdapat pada perlakuan dengan skor rata-rata tertinggi yaitu 3,05 pada perlakuan T3.

Aroma harum yang dihasilkan dikarenakan aroma dasar molases yang harum. Molases yang diberikan pada perlakuan T3 mempunyai jumlah lebih banyak sehingga menyebabkan aroma yang lebih harum. Faktor yang dapat mempengaruhi aroma MnB yaitu bahan penyusun dan kandungan nutrien dari bahan. Krisnan \& Ginting (2009) menyatakan bahwa aroma pakan yang segar dapat meningkatkan palatabilitas pakan. Kambing mempunyai sifat memilih-milih pakan yang akan dikonsumsinya. Yusmadi et al. (2008) menyatakan bahwa rangsangan penciuman (bau/aroma) pada ruminansia merupakan salah satu faktor penting dalam mencari dan memilih pakan yang akan dikonsumsi. Davendra \& Burns (1994) menyatakan kambing mempunyai kemampuan dalam membedakan rasa pahit, manis, asam dan asin serta mempunyai toleransi tinggi terhadap rasa pahit. Simanihuruk \& Sirait (2010) menyatakan bahwa kandungan gula yang terdapat dalam molases dapat meningkatkan konsumsi pada ternak kambing. Aroma pakan dapat mempengaruhi tingkat palatabilitas ternak. Santi et al. (2012) menyatakan bahwa pengunaan molases dapat meningkatkan palatabilitas pakan karena mempunyai aroma yang harum. Aroma pakan yang disukai oleh ternak adalah harum, segar dan tidak tengik (Ismi et al. 2017). Aroma yang paling harum akan mempengaruhi palatabilitas pakan dan penerimaan kepada ternak.

\section{SIMPULAN}

Multinutrien blok dengan pemberian aras molases sebanyak 50\% memiliki kualitas organoleptik yang paling baik ditinjau dari tekstur dan aroma..

\section{DAFTAR PUSTAKA}

Devendra C \& Burns M. 1994. Produksi Kambing di Daerah Tropis. Bogor (ID) : Institut Pertanian Bogor Press

Fathia N. 2006. Uji sifat fisik dan mekanik pakan ikan buatan dengan binder tepung tapioka. [skripsi]. Bandar Lampung (ID): Fakultas Pertanian Universitas Lampung.

Garcia LO \& Restrepo JIR. 1995. Multinutrient Block Handbook (FAO Better Farming Series no. 45). Rome (IT): Food and Agriculture Organization of United Nation.

Hermawan, R Sutrisna \& Muhtarudin. 2015. Kualitas fisik, kadar air, dan sebaran jamur pada wafer limbah pertanian dengan lama simpan berbeda. Jurnal Ilmu Peternakan Terpadu. 3 (2): 55 - 60

Ismi RS, Pujaningsih RI \& Sumarsih S. 2017. Pengaruh penambahan level molases terhadap kualitas fisik dan organoleptik pakan kambing periode penggemukan. Jurnal Ilmu Petenakan. 5 (1): 5863

Krisnan R \& Ginting SP. 2009. Penggunaan Solid Ex-Decanter sebagai binder pembuatan pakan komplit berbentuk pellet: Evaluasi fisik pakan komplit berbentuk pellet. Bogor (ID): Seminar Nasional Teknologi Peternakan dan Veteriner. Bogor Litbang Pertanian

Kurnia F, Suhardiman M, Stephani L \& Purwadaria T. 2012. Peranan nano-mineral sebagai bahan imbuhan pakan untuk meningkatkan produktivitas dan kualitas produksi ternak. Wartazoa. 22 (4): 187 - 194

Pratama N, Djamas D \& Darvina Y. 2016. Pengaruh variasi ukuran partikel terhadap nilai konduktivitas termal papan partikel tongkol jagung. Jurnal Pillar of Physics. 7 (1): 25 - 32

Santi RK, Fatmasari D, Widyawati SD \& Suprayogi PS. 2012. Kualitas dan nilai kecernaan in vitro silase batang pisang (Musa paradisiaca) dengan penambahan beberapa akselerator. Jurnal Tropical Animal Husbandry. 1 (1): 15 - 23

Simanihuruk K \& Sirait, J. 2010. Silase kulit buah kopi sebagai pakan dasar pada kambing boerka sedang tumbuh. Bogor (ID): Seminar Nasional Teknologi Peternakan dan Veteriner. Litbang Pertanian

Syahri M, Retnani Y \& Khotijah L. 2018. Evaluasi penambahan binder berbeda terhadap kualitas fisik mineral wafer. Bulletin Makanan Ternak. 16 (1): 24-35 
Syukur A \& Suharno B. 2014. Bisnis Pembibitan Kambing. Yogyakarta (ID): Penebar Swadaya,

Toharmat T, Nurasih E, Nazilah R, Hotimah N, Noerzihad TQ, Sigit NA \& Retnani Y. 2005. Sifat fisik pakan kaya serat dan pengaruhnya terhadap konsumsi dan kecernaan nutrien ransum pada kambing. Media Peternakan. 29 (3): $146-154$

Triyanto E, Prasetiyono BWHE \& Mukodiningsih S. 2013. Pengaruh bahan pengemas dan lama simpan terhadap kualitas fisik dan kimia wafer pakan komplit berbasis limbah agroindustri. Jurnal Animal Agriculture. 2 (1): 400 - 409.

Warsy, Chadijah S \& Rustiah W. 2016. Optimalisasi kalsium karbonat dari cangkang telur untuk produksi pasta komposit. Al-Kimia. 4 (2): $86-97$

Widiastuti R. 2013. Kualitas pellet berbasis sisa pangan foodcourt dan limbah sayuran fermentasi sebagai bahan pakan fungsional ayam broiler. [tesis] Semarang (ID): Fakultas Peternakan dan Pertanian Universitas Diponegoro

Yusmadi, Nahrowi \& Ridla M. 2008. Kajian mutu dan palatabilitas silase dan hay ransum komplit berbasis sampah organik primer pada kambing Peranakan Etawah. Agripet. 8 (1): 31 - 38.

Zakaria ZA B, Zakaria N \& Kasim Z. 2014. Mineral composition of the cockle (Anadara granosa) shells, hard clamp (Meretrix meretrix) shells and corais (Porites spp.): a comparative study. Journal Animal Veterinary Advances. 3 (7): 445 - 447 